\title{
Decreased deposition of sulphate and the responses in soilwater at Estonian integrated monitoring sites 1995-2004
}

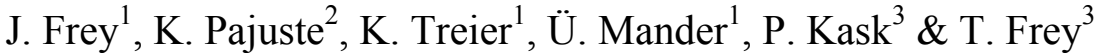 \\ ${ }^{1}$ Institute of Geography, University of Tartu, Estonia \\ ${ }^{2}$ Estonian Environmental Research Centre, Tallinn, Estonia \\ ${ }^{3}$ Estonian University of Life Sciences, Tartu, Estonia
}

\begin{abstract}
This paper presents the results of trend analyses of a ten-year study of deposition (throughfall+stemflow) and soilwater in two pine stands and a spruce stand (ICP IM areas). The reported decreasing trends of deposited sulphate and cations at the easterly located Saarejärve integrated monitoring area are in good agreement with the decline of $\mathrm{SO}_{2}$ and fly ash emissions in Estonia. At Vilsandi pine stand, which has the westernmost location and is under a marine influence, the decrease of sulphur deposition was comparable with that of the eastern Saarejärve pine stand. However, total base cation load in Vilsandi pine stand remained unchanged resulting in a decrease of throughfall acidity. At Saarejärv coniferous stands deposition of base cations decreased more than that of acid anions causing an increase in $\mathrm{K}$ leaching from canopies. A good accordance between sulphate decline in deposition and topsoil water was accompanied by base cation decline in soilwater under organic horizon at both IM areas. In podzolized soil at Saarejärve the decline of $\mathrm{SO}_{4}$ and base cations resulted in increased levels of total soluble Al.
\end{abstract}

Keywords: deposition, throughfall, stemflow, pine and spruce stand, soilwater, sulphate, cations, aluminium, trend analyses.

\section{Introduction}

Predominant sources of $\mathrm{SO}_{2}$ and particle emission in Estonia are four large oilshale-based thermal power plants and chemical industries in the Northeastern region. Oil shale mining and combustion accounted for about $81 \%$ of total 
harmful emissions up till 2005. Estonian oil shale as a fuel is characterized by high ash share (45-50\%) and moderate sulphur content (1.4-1.8\%). A peculiarity of Estonian oil shale is its chlorine content $(0.75 \%)$ combined with organic matter. Oil-shale-centred energetics and economy have led to specific deposition patterns. The high amount of alkaline dust emitted contributed to a considerable neutralization of acid pollutants already in the atmosphere, and even resulted in alkalinization and damage of sensitive ombrotrophic raised bogs [1]. A rapid decrease in emissions took place in 1990s due to reshaping of local economy after restoration of independent statehood in 1991. During the study period (1995-2004), the quantities of emitted $\mathrm{SO}_{2}$ and fly ash decreased by $40 \%$ and $65 \%$, respectively, mostly due to a decline in annually combusted oil shale amounts (from about 24 megatons in 1994 to 13 megatons in 2004) i.e. due to a decrease in production of electric energy in the power plants.

The decrease of emissions led to a decline in concentrations of both anions $\left(\mathrm{SO}_{4}\right.$ and $\left.\mathrm{Cl}\right)$ and cations $(\mathrm{Ca}, \mathrm{Mg}, \mathrm{Na}$ and $\mathrm{K}$ ) in bulk precipitation at all Estonian monitoring stations during 1994-2001 [2].

The first long-term national intensive ecosystem monitoring programme in Estonia: International Co-operative Programme on Integrated Monitoring (ICP IM) under LTRAP Convention was initiated by the Nordic Council of Ministers in 1994 [3]. In the framework of ICP IM, an intensive monitoring site at Lake Saare forested catchment area in eastern Estonia and a biomonitoring site in the westernmost Island Vilsandi were established. The IM monitoring sites represent areas of boreal coniferous forest receiving background loads of air pollution and deposition. Although the two sites are not regionally representative, they provide an opportunity to monitor changes in air pollution and its impacts on the environment of coniferous stands at the western border of Estonia (Vilsandi), where higher concentrations of $\mathrm{SO}_{2}$ are measured from southern and southwestern air mass transport direction [4], and in eastern Estonia (Lake Saare area), which is more affected by local sources of air pollution from the region of oil shale industry in North-Eastern Estonia.

The current paper presents results of a ten-year study of throughfall, stemflow and soilwater in two pine stands and one spruce stand under the conditions of declining $\mathrm{SO}_{2}$ and base cation emissions.

\section{Material and methods}

\subsection{Site characteristics}

The study was carried out in the forested subcatchment area (109 ha) of Lake Saare in eastern Estonia $\left(58^{\circ} 39^{\prime} \mathrm{N}, 26^{\circ} 45^{\prime} \mathrm{E}\right)$, hereafter referred to as Saarejärve, and in Vilsandi, Estonia's westernmost island $\left(58^{\circ} 34^{\prime} \mathrm{N}, 21^{\circ} 50^{\prime} \mathrm{E}\right)$. At Saarejärve water and litter samples were collected from two permanent plots of the Scots pine (120 years old) and the Norway spruce (90 years old) stands. The permanent plots are situated on nearly flat surfaces, in areas representative of dominant forest site types in the catchment area. The Rhodococcum type Scots pine stand is located at an elevation. The Vaccinium type Norway spruce stand is 
situated lower than the pine stand, near the bottom of a slope. At both stands the parent material is glaciofluvial sand, on which moderately eluviated Haplic Podzols have developed.

The permanent plot in Vilsandi is a 100-year-old Scots pine stand (Fragaria type) on Calcari-Gleyic Leptosol.

Mean annual precipitation during the study period (1995-2004) was $630 \mathrm{~mm}$ at Saarejärve and $535 \mathrm{~mm}$ in Vilsandi.

Table 1: $\quad$ Stand characteristics of sample plots.

\begin{tabular}{|l|l|l|l|}
\hline Permanent plot & $\begin{array}{l}\text { Vilsandi } \\
\text { pine stand }\end{array}$ & $\begin{array}{l}\text { Saarejärve } \\
\text { pine stand }\end{array}$ & $\begin{array}{l}\text { Saarejärve } \\
\text { spruce stand }\end{array}$ \\
\hline Site type & $\begin{array}{l}\text { Fragario- } \\
\text { Pinetum }\end{array}$ & $\begin{array}{l}\text { Rhodococco- } \\
\text { vitis-idaeo- } \\
\text { Pinetum }\end{array}$ & $\begin{array}{l}\text { Vaccinio- } \\
\text { myrtilli- } \\
\text { Piceetum }\end{array}$ \\
\hline Soil type & $\begin{array}{l}\text { Calcari- } \\
\text { Gleyic } \\
\text { Leptosol }\end{array}$ & Haplic Podzol & $\begin{array}{l}\text { Haplic } \\
\text { Podzol }\end{array}$ \\
\hline Age of dominant trees & 100 & 120 & 90 \\
\hline Number of trees in ha & 440 & 551 & 672 \\
\hline Mean diameter (m) & 0.29 & 0.37 & 0.26 \\
\hline Mean height (m) & 16.9 & 28.7 & 22.5 \\
\hline $\begin{array}{l}\text { Annual average throughfall } \\
\text { amount (mm) }\end{array}$ & 282 & 513 & 430 \\
\hline $\begin{array}{l}\text { Annual average soilwater amount } \\
\text { from depth of } 10 \mathrm{~cm}(\mathrm{~mm})\end{array}$ & 101 & 57 & 113 \\
\hline $\begin{array}{l}\text { Annual average soilwater amount } \\
\text { from depth of } 40 \mathrm{~cm}(\mathrm{~mm})\end{array}$ & 98 & 25 & 74 \\
\hline
\end{tabular}

\subsection{Sampling and chemical analyses}

Bulk deposition was collected using two NILU-type collectors [5] at both monitoring areas. Throughfall deposition was collected by polyethylene funneltype bulk collectors $(20 \mathrm{~cm}$ in diameter, at a height of about $150 \mathrm{~cm}$ ) in snow free time, and by buckets during winter. Spiral silicone collectors fitted to three trees per plot were used for collecting stemflow. Water volumes were measured on the field by graduated cylinder. Sampling frequencies were once a fortnight in summer and once a month in winter. Sampling areas and stand characteristics are given in table 1 .

Soil water was sampled with zero-tension plate lysimeters of $0.1 \mathrm{~m}^{2}$ [6]. At Saarejärve pine and spruce stands the lysimeters were inserted into depths of 5 to $10 \mathrm{~cm}$ under organic horizon and about $40 \mathrm{~cm}$ under eluvial horizon with 6 replications per depth. At Vilsandi the lysimeters were installed under humus horizon (into depth of 5 to 10) and illuvial horizon $\left(\mathrm{BC}_{\mathrm{g})}\right.$ into depth of about 35 $\mathrm{cm})$. At both sites percolation water was collected approximately at 1-month intervals during the snow-free period along with deposition samples.

Water samples from Vilsandi and Saarejärve were analyzed in the Estonian Environmental Research Centre in Tallinn and in the Environmental Studies 
Laboratory in Tartu, respectively. Both laboratories have continuous quality control programmes, and they participate regularly in international intercalibration exercises.

Major anions $\left(\mathrm{Cl}^{-}, \mathrm{NO}_{3}{ }^{-}, \mathrm{SO}_{4}{ }^{2-}\right)$ in precipitation and soilwater were analysed by ion chromatography. Base cations were determined using atomic absorption spectroscopy or ion chromatography depending on laboratory, $\mathrm{pH}$ was measured potentiometrically.

The nonparametric Mann-Kendall test was used to estimate significance $(p<0.05)$ of the trends in annual values. The slope of a linear trend was estimated with the nonparametric Sen's method [7].

\section{Results}

\subsection{Decline of sulphur deposition}

During 1995-2004 a significant decline was observed in concentration and deposition of sulphate in bulk precipitation and in pine and spruce stands' throughfall and stemflow at the integrated monitoring sites in Estonia (Table 2). Mean annual concentration of $\mathrm{SO}_{4}-\mathrm{S}$ in bulk precipitation decreased from $2.2 \mathrm{mg}$ $1^{-1}$ to $0.37 \mathrm{mg} \mathrm{l}^{-1}$ at Saarejärve and from 1.4 to $0.51 \mathrm{mg} \mathrm{l}^{-1}$ at Vilsandi. Sulphur load dropped from 9.1 to $3.2 \mathrm{~kg} \mathrm{ha}^{-1} \mathrm{yr}^{-1}$ at Saarejärve. At Vilsandi the highest load was $5.1 \mathrm{~kg} \mathrm{ha}^{-1} \mathrm{yr}^{-1}$ in 1995 and the lowest $2.4 \mathrm{~kg} \mathrm{ha}^{-1} \mathrm{yr}^{-1}$ in 2002 .

The prevailing anion in throughfall of the pine and spruce stand at Saarejärve was $\mathrm{SO}_{4}{ }^{2-}$, which formed $58 \%$ and $66 \%$ of summed anions, respectively. Sea salt correction shows that marine fraction of sulphur is less than $8 \%$ in bulk- and throughfall precipitation at Saarejärve. At the remote island Vilsandi, however, the prevailing anion in throughfall was $\mathrm{Cl}^{-1}(53 \%)$, sulphate formed only $29 \%$ of summed anions. Marine fraction of sulphate was on average $10 \%$ in bulk deposition and $25 \%$ in throughfall flux.

The throughfall flux of S decreased significantly from 8.2 and $18.8 \mathrm{~kg} \mathrm{ha}^{-1}$, in 1995 to 4.2 and $4.8 \mathrm{~kg} \mathrm{ha}^{-1}$ in 2004 in Saarejärve pine and spruce stands, respectively. At Vilsandi pine stand the decrease in sulphur deposition was about the same as in Saarejärve pine stand (50\%) (Fig. 1). The concentration of the other two main anions $\left(\mathrm{NO}_{3}\right.$ and $\left.\mathrm{Cl}\right)$ also seems to have decreased along with the decline of sulphate at Vilsandi pine stand (Fig. 1). Comparison of TF from the two monitoring sites shows that $\mathrm{NO}_{3}-\mathrm{N}$ deposition is higher at Vilsandi $(2.3 \mathrm{~kg}$ $\left.\mathrm{ha}^{-1}\right)$ than Saarejärve (1.0-1.4 $\left.\mathrm{kg} \mathrm{ha}^{-1}\right)$ pine stand. The decrease of nitrate deposition on Fig.1 could be explained by variation between the selected monitoring years. Furthermore, throughfall $\mathrm{NO}_{3}$ content is more influenced by internal cycling in canopy [8] than the $\mathrm{SO}_{4}$ content.

Actual annual $\mathrm{S}$ input flux into the soil comes from $\mathrm{S}$ of throughfall, stemflow and litterfall. Stemflow water was usually negligible in volume forming $2-5 \%$ of throughfall in the spruce and pine stand at Saarejärve and less than $1 \%$ in the pine stand at Vilsandi. However, due to the high concentration of $\mathrm{SO}_{4}-\mathrm{S}$, significant transport of $\mathrm{S}$ took place by stemflow, at least at Saarejärve, in the first years of the monitoring period. Sulphur input by litterfall formed on average one third of total $\mathrm{S}$ input $(\mathrm{TF}+\mathrm{SF}+\mathrm{LF})$ in the studied stands. 

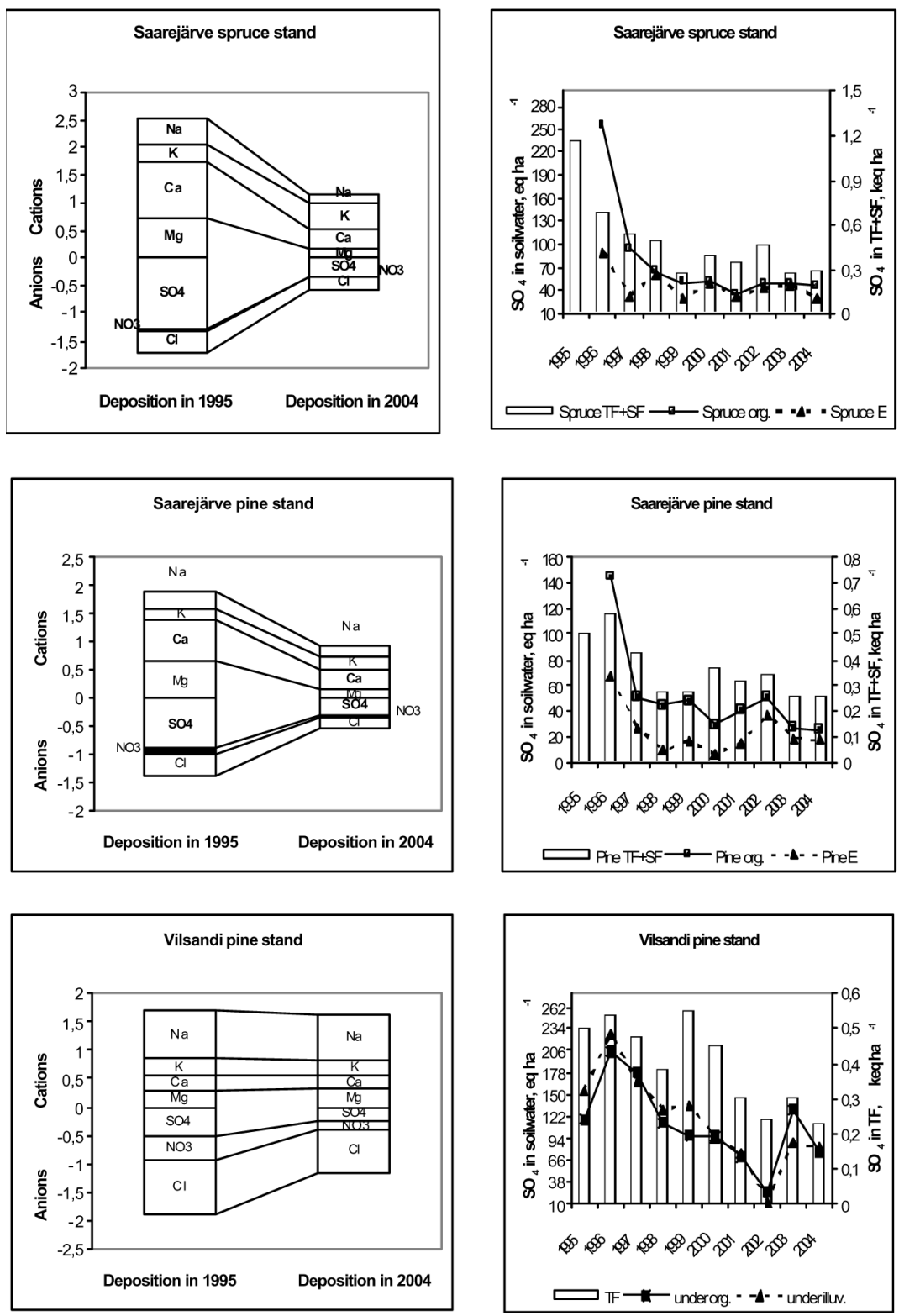

Figure 1: Decline of throughfall+stemflow deposition (keq ha $\mathrm{y}^{-1}$ ), comparison of first and last monitoring years in spruce stand and pine stand at Saarejärve and Vilsandi on the left side. Sulphate decline in deposition (throughfall+stemflow) and in soilwater under organic (org.) and eluvial (E) horizons of spruce and pine stands at Saarejärve and under organic and illuvial (illuv.) horizons in Vilsandi pine stand on the right side. 
During the study period the actual $S$ input decreased about 2 times in the pine stands and 4 times in the spruce stand. It should also be pointed out that, judging by annual litterfall amounts (needles only); the crown needle surface of spruce canopy is about three times bigger than that of pine canopy. The sulphur content in litter will be a more important part in the S-circle due to decreased atmospheric loads of $\mathrm{S}$.

\subsection{Decline of base cation deposition}

The decreasing trend of $\mathrm{SO}_{4}{ }^{2-}$ concentration in throughfall+stemflow is in good accordance with decreasing trends of the concentrations of most important base cations, $\mathrm{Ca}$ and $\mathrm{Mg}$ at Saarejärve coniferous stands. The share of $\mathrm{Ca}^{2+}$ and $\mathrm{Mg}^{2+}$ was on average $45 \%$ and $15 \%$ of summed cations, respectively. Decreasing flux of summed base cations $(\mathrm{Ca}+\mathrm{Mg}+\mathrm{K}+\mathrm{Na})$ during the study period was statistically significant at Saarejärve (Table 2).

Table 2: $\quad$ Trends in data series ("“-"decreasing and "+" increasing) of annual mean concentration in throughfall $(\mathrm{TF}+\mathrm{SF})$ and soil water $(\mathrm{SW})$ from 1995-2004. Estimated by Mann-Kendall nonparametric test (significance levels $* * * \mathrm{p}<0.001 ; * * \mathrm{p}<0.01 ;{ }^{*} \mathrm{p}<0.05$ ).

\begin{tabular}{|l|l|l|l|l|l|l|l|l|l|}
\hline Stand & \multicolumn{2}{|c|}{ Saarejärve spruce stand } & \multicolumn{3}{|c|}{ Saarejärve pine stand } & \multicolumn{3}{|c|}{ Vilsandi pine stand } \\
\hline & $\begin{array}{l}\mathrm{TF}+ \\
\mathrm{SF}\end{array}$ & $\begin{array}{l}\mathrm{SW} \\
10 \mathrm{~cm}\end{array}$ & $\begin{array}{l}\mathrm{SW} \\
40 \mathrm{~cm}\end{array}$ & $\begin{array}{l}\mathrm{TF}+ \\
\mathrm{SF}\end{array}$ & $\begin{array}{l}\mathrm{SW} \\
10 \\
\mathrm{~cm}\end{array}$ & $\begin{array}{l}\mathrm{SW} \\
40 \mathrm{~cm}\end{array}$ & $\begin{array}{l}\mathrm{TF}+ \\
\mathrm{SF}\end{array}$ & $\begin{array}{l}\mathrm{SW} \\
17 \\
\mathrm{~cm}\end{array}$ & $\begin{array}{l}\mathrm{SW} \\
35 \mathrm{~cm}\end{array}$ \\
\hline $\mathrm{SO}_{4}$ & - & $-* * *$ & $-* * *$ & $-*$ & - & $-*$ & $-*$ & $-*$ & $-*$ \\
\hline $\mathrm{Ca}$ & $-* *$ & $-*$ & + & $-*$ & - & - & & & \\
\hline $\mathrm{Mg}$ & $-* *$ & $-*$ & $-* * *$ & $-*$ & - & $-*$ & & $-*$ & \\
\hline $\mathrm{K}$ & + & $-*$ & $-* *$ & + & - & - & & $-*$ & \\
\hline $\begin{array}{l}\text { Sum of } \\
\text { cations }\end{array}$ & $-* *$ & $-* *$ & $-*$ & $-*$ & - & $-*$ & & $-*$ & \\
\hline $\begin{array}{l}\text { Sum of } \\
\text { anions }\end{array}$ & $-* *$ & - & $-*$ & $-*$ & - & $-*$ & & & \\
\hline $\mathrm{Al}_{\mathrm{Tot}}$ & & + & $+* *$ & & $+*$ & + & & & \\
\hline $\mathrm{Al}^{3+}$ & & - & $-*$ & & $+*$ & $+* * *$ & & & \\
\hline $\mathrm{H}^{+}$ & - & $+*$ & + & $*+$ & + & $-*$ & $-*$ & $+*$ & \\
\hline
\end{tabular}

There was a clear change in proportion of various cations in throughfall. Proportions of $\mathrm{Ca}^{2+}$ and $\mathrm{Mg}^{2+}$ in summed cations decreased by $0.1 \%$ and $0.4 \%$ per year, accordingly, in pine throughfall, while the proportion of $\mathrm{K}$ increased by $1.6 \%$ per year $(\mathrm{p}<0.05)$ obviously due to leaching $(\mathrm{K}$ did not increase in open area precipitation). In the spruce stand the decrease of the share of $\mathrm{Ca}^{2+}$ and $\mathrm{Mg}^{2+}$ in summed cations was $1.2 \%$ and $0.38 \%$ per year, accordingly, and the increase of $\mathrm{K}^{+}$due to leaching was $2.8 \%$ per year $(\mathrm{p}<0.05)$.

Due to its location the dominant cation in Vilsandi $\mathrm{TF}$ is $\mathrm{Na}(40 \%$ of summed cations on average), the remaining $60 \%$ is $\mathrm{Ca}+\mathrm{Mg}+\mathrm{K}$ in almost equal parts. There was no significant decreasing trend of base cation concentration or deposition at the Vilsandi pine stand. 
At Vilsandi deposition of base cations neutralised the acidic deposition in bulk precipitation to a larger extent than in throughfall, while $\mathrm{H}+$ flux also decreased in the throughfall of the pine stand. At the same time bulk precipitation was more acidic than total deposition in the pine and spruce stands at Saarejärve. The annual mean $\mathrm{pH}$ decreased in the bulk deposition (from 4.8 to 4.7) as well as in the throughfall (from about 5.4 to 5.2) during the study period, and the increase of $\mathrm{H}+$ flux in the pine stand was significant (Table 2).

\subsection{Responses of soil solution chemistry to decline of deposition}

There were statistically significant declines in sulphate concentration, sum of cations and $\mathrm{pH}$ (from 5.5 to 4.9) in soilwater under organic horizon at Vilsandi. At Saarejärve statistically significant declining trends in sulphate concentration, sum of cations and sum of strong anions $\left(\mathrm{SO}_{4}+\mathrm{Cl}+\mathrm{NO}_{3}\right)$ were estimated in soilwater under both horizons of the spruce stand, and under eluvial horizon of the pine stand. Concentrations of $\mathrm{SO}_{4}$ and of most cations also decreased below the organic horizon of the pine stand but the trends were not significant (Table 2). $\mathrm{SO}_{4}$ concentrations were about $10 \%$ higher in soilwater under the eluvial horizon than under the organic horizon at Saarejärve. Likewise, a statistically significant decreasing timetrend of sulphate amount in soil water output from organic horizon was observed in the spruce and pine stands at Saarejärve. The output of sulphate flux from organic horizon decreased from 0.25 to $0.05 \mathrm{keq} \mathrm{ha}^{-}$ ${ }^{1} \mathrm{y}^{-1}$ (about 5 times) in the spruce stand and from 0.14 to $0.025 \mathrm{keq} \mathrm{ha}^{-1} \mathrm{y}^{-1}$ (6 times) in the pine stand at Saarejärve area. The decline of sulphate output fluxes from deeper horizons was not statistically significant, although leaching from eluvial horizon in the spruce stand decreased from 90 to $30 \mathrm{eq} \mathrm{ha}^{-1} \mathrm{y}^{-1}$ and in the pine stand from 67 to $18 \mathrm{eq} \mathrm{ha}^{-1} \mathrm{y}^{-1}$. At the remote island Vilsandi sulphate output fluxes decreased from 0.12 to $0.08 \mathrm{keq} \mathrm{ha}^{-1} \mathrm{y}^{-1}$ (1.5 times) under organic horizon and from 0.16 to $0.08 \mathrm{keq} \mathrm{ha}^{-1} \mathrm{y}^{-1}$ (about 2 times) under illuvial horizon. $\mathrm{SO}_{4}$ content under deeper (B) horizon was remarkable higher in Vilsandi pine stand than at Saarejärve (Fig.1 on the right).

The decline in soilwater sulphate was to a great extent matched by a decrease in most cations in organic horizons of the spruce and pine stands, and to a lesser extent also in the eluvial horizon of both stands at Saarejärve. In the soilwater of carbonate-rich soil at Vilsandi the cation content decreased in good accordance with $\mathrm{SO}_{4}$ decline under organic horizon but was not influenced by a decline of sulphate in illuvial horizon.

Total soluble Al contents increased in the soil water from both depths of both stands at Saarejärve (Table 1), although the trends were statistically significant only below organic horizon in the spruce stand and below eluvial horizon in the pine stand.

\section{Discussion}

Decrease in sulphur deposition is often accompanied by decline of base cations. At Vilsandi pine stand the total deposition of summed base cations did not 
significantly decrease while the cation flux under humus horizon decreased significantly during the monitoring period. Thereby, it could be suggested that a substantial share of cations got deposited not along with sulphate ions at Vilsandi. On the other hand $\mathrm{SO}_{4}$ from deposition plays important role as an accompanying anion for cations, which readily moves down with percolation water through organic horizon.

Throughfall composition forming processes (dry deposition, interception, leaching) in canopy changed in both stands at Saarejärve during the study period. Deposition of anions via throughfall and stemflow decreased by about $1 \mathrm{keq} \mathrm{ha}^{-1}$ in the spruce stand and $0.8 \mathrm{keq} \mathrm{ha}{ }^{-1}$ in the pine stand. At the same time deposition of cations at Saarejärve decreased by 1.5 and $1 \mathrm{keq} \mathrm{ha}^{-1}$ in the spruce and pine stands, respectively. Since the input of dust-associated base cations decreased more than the acid anion input, acidity of throughfall should increase, and cause increased leaching of $\mathrm{K}$ from canopies.

Good accordance between sulphate decline in deposition and topsoil water is partly due to the use of zero-tension lysimeters. Percolation water obtained by zero-tension lysimeters is the soil water fraction that is primarily involved in soil formation processes, e.g. transport of ions down the soil profile, from one horizon to another prior to e.g. buffering processes [9].

The decline of sulphate fluxes in deposition and under organic horizon of soil water at Saarejärve area resulted in a decrease of $\mathrm{SO}_{4}$ retention in organic horizon. The retention of sulphate via adsorption processes decreased from about 0.44 to $0.24 \mathrm{keq} \mathrm{ha}^{-1}$ in the spruce and pine stands suggesting a decrease in consumption of protons (potential increase of $\mathrm{H}^{+}$) by about $0.2 \mathrm{keq} \mathrm{ha}^{-1}$ in the spruce and pine stands' organic horizon. The decline in the retention of sulphate in eluvial horizon occurred to a lesser extent, and resulted in the potential increase of $\mathrm{H}^{+}$by about 0.15 and $0.07 \mathrm{eq} \mathrm{ha}^{-1}$ in the spruce and pine stand, respectively. Via proton consumption the sulphate retention had a decisive role in proton budgets in organic layers of the spruce and pine stands at Saarejärve in the first five years of the monitoring period [10]. The decline in $\mathrm{SO}_{4}$ retention in Vilsandi organic horizon was $0.16 \mathrm{keq} \mathrm{ha}^{-1}$, which is about the same as in Saarejärve. Higher output of $\mathrm{SO}_{4}$ from illuvial horizon than from organic horizon indicates suitable conditions for adsorption/desorption processes. The increase of $\mathrm{H}^{+}$in percolation water of both horizons in the spruce stand and under the organic horizon of the pine stands could be due to changes in $\mathrm{SO}_{4}$ retention, as well as due to the decline of summed cations in soilwater, which reflects intensive accumulation of base cations into biomass or/and a shortage of exchangeable cations in soil. Although desorption of $\mathrm{SO}_{4}$ anion appeared to be much slower than adsorption [11], the previously adsorbed sulphate would have got released and thus delayed the decrease of $\mathrm{SO}_{4}$ concentration in deeper horizons.

Only additional $\mathrm{H}^{+}$can increase both total $\mathrm{Al}$ and soluble free $\mathrm{Al}^{3+}$ concentration in soil water. The $\mathrm{pH}$ of solutions in the studied soil water was normally well below 5 at Saarejärve and, in fact, the $\mathrm{pH}$ of throughfall was commonly higher than that of the soil solution receiving it. The increase of total soluble $\mathrm{Al}$ in podzolized soil indicates an ongoing process of podzolization due 
to dissociated organic acids derived from mineralisation of conifer litter, and is probably attributable to decreased retention of sulphate in soil horizons.

\section{Conclusions}

The decreasing trends of deposited sulphate and cations at Saarejärve integrated monitoring area are in good agreement with the decline of $\mathrm{SO}_{2}$ and fly ash emissions in Estonia, as well as with $\mathrm{SO}_{4}$ time series from local precipitation monitoring stations during the study period. At Vilsandi pine stand, which has the westernmost location and is under marine influence, the decrease of sulphur deposition was comparable with that of the eastern Saarejärve pine stand, but the total base cation load in Vilsandi pine stand remained unchanged over the entire monitoring period resulting in a decrease of throughfall acidity. Deposition of base cations at Saarejärve coniferous stands decreased more than that of acid anions causing an increase in $\mathrm{K}$ leaching from canopies.

A good accordance between sulphate decline in deposition and in topsoil water was accompanied by base cation decline in soilwater under organic horizon at both IM areas. In podzolized soil at Saarejärve the decline of $\mathrm{SO}_{4}$ and base cations resulted in increased levels of total soluble Al.

\section{Acknowledgements}

This study was supported by Estonian Science Foundation grant No. 6083 and Target Funding Project No. 0182534s03 of the Ministry of Education and Science of Estonia.

\section{References}

[1] Karofield, E., The effects of alkaline fly ash precipitation on the Sphagnum mosses in Niinesaare bog, NE Estonia, Suo 47, pp. 105-114, 1996.

[2] Treier, K., Pajuste, K. and Frey, J., 'Recent trends in chemical composition of bulk precipitation at Estonian monitoring stations 19942001', Atmospheric Environment 38, pp. 7009-7019, 2004.

[3] TemaNord, Establishing of the Baltic Integrated Monitoring (BIM) sites 1992-1994, in, Nordic Council of Ministers, Copenhagen, pp. 1-44, 1996.

[4] Pajuste, K., Kimmel, V., Kohv, N. and Truuts, T., Assessment of the Estonian EMEP data, in, Assessment of the EMEP measurements and modelling work in Europe from 1977 until today, http://www.emep.int/assessment/estonia.pdf, 2003.

[5] EMEP: EMEP manual for sampling and chemical analysis, in, EMEP/CCC-Report 1/95, Chemical Co-ordinating Centre, Norwegian Institute for Air Research, Kjeller, pp. 1-199, 1996.

[6] Voll, M. and Roots, O., Soil water sample collector, Environmental Monitoring and Assessment 54, pp. 283-287, 1999. 
[7] Salmi, T., Määttä, A., Anttila, P., Ruoho-Airola. T. and Amell, T., Detecting trends of annual values of atmospheric pollutants by MannKendall test and Sen's slope estimates - the Excel template application MAKESENS, in, Publication on Air Quality 31, Finnish meteorological Institute, Helsinki, pp.1-35, 2002.

[8] Pajuste, K., Frey, J. and Asi, E., Interactions of atmospheric deposition with coniferous canopies in Estonia. Environmental Monitoring and Assessment 112, pp. 177-196, 2006.

[9] Derome, J., Lindroos, A.J. and Niska, K., Comparison of soil water and percolation water quality, in, Forest Condition Monitoring in Finland. National report 1998, 748. The Finnish Forest Research Institute, Helsinki, pp. 132-137, 1999.

[10] Frey, J., Frey, T. and Pajuste, K., Input-output analysis of macroelements in ICP-IM catchment area, Estonia, Landscape and Urban Planning 67, pp. 217-223, 2004.

[11] McBride, M.B., Chemisorption and Precipitation of Inorganic Ions', in, Environmental Chemistry of Soils, Oxford University Press, New York, pp. 121-164, 1994. 